\title{
THE LEGACY OF THE PENNSYLVANIA COLLEGE OF OPTOMETRY
}

\author{
Alexis R. Abate, M.A. \\ Director of Communications \\ Salus University \\ aabate@salus.edu
}

Anthony Di Stefano, O.D., M.Ed., M.P.H.

Professor Emeritus

Salus University

tdistefano@salus.edu

doi: 10.14434/hindsight.v50i4.28034

\section{ABSTRACT}

This article outlines the 100-year history of Salus University from its founding as the Pennsylvania State College of Optometry in 1919 by Dr. Albert Fitch, through its growth into an integrated health sciences university. The article describes the university's evolving mission, academic diversification and physical expansion during the last century.

\section{KEYWORDS}

PCO; PSCO; Salus University; Pennsylvania College of Optometry; Pennsylvania State College of Optometry; Albert Fitch

\section{INTRODUCTION}

Salus University continues a 100-year legacy that began with the establishment of the Pennsylvania State College of Optometry (PSCO) in Philadel phia. Today Salus is a diversified, globally recognized, health professions university that offers a wide range of accredited post-graduate and professional degree programs. Currently, the University has more than 1,200 students and more than 14,000 alumni worldwide.

Although the name Salus University may still be young (2008), the history and reputation of our founding institution, the Pennsylvania College of Optometry (PCO), is known and respected around the world. Changes in the nation's health care delivery system are significantly altering every facet of our medical and health science professions. Central to the Salus mission is keeping pace with the rapidly expanding health care system, setting national trends and standards, and being the leader in providing the nation's top health science, education and rehabilitation professionals.

Shakespeare knew the power and magic of words. He understood that within each word — each name - there lies a story, a symbol, or a deeper meaning that touches our senses, our intellect and our heart. The choice of Salus as the name of our academic home reflected a historical moment in our evolution. In order to appreciate that moment, a journey back in historical consciousness - not to live there, but to again feel, smell and experience the texture of our institutional history and how those aspirations gave birth to who we are today-is important.

\section{THE OPTOMIST OPTOMETRIST: DR. ALBERT FITCH AND THE MAKING OF THE PENNSYLVANIA COLLEGE OF OPTOMETRY (PCO)}

Those who think futuristically are often at risk for public ridicule, but with a lot of motivation and confidence in their dreams they often succeed. A select few of those who succeed are lucky enough to be considered visionaries. PSCO founder, Dr. Albert Fitch, was considered a visionary by his peers and a revolutionary by others in the health care community. (Figure 1) His goal in establishing PSCO as

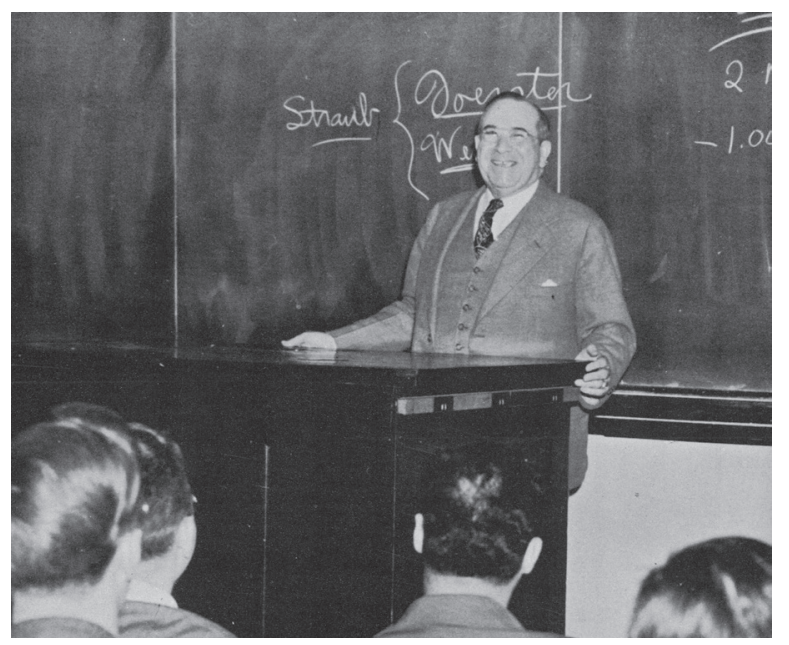

Figure 1. Dr. Albert Fitch teaching. Image courtesy Salus University

a nonprofit educational institution in 1919 was to create a professional school of optometry comparable to those of medicine and dentistry. "His desire was to "obtain a higher 
standard of proficiency and to enlighten the public mind on the subject and science of optometry and its relationship to the conservation of vision". That desire to set and maintain a higher standard of education is evident today at Salus University, where the institution continues to break new ground with creative and innovative curricula for all of its degree programs.

Dr. Fitch was also PSCO's first president, serving from 1919 until his death in February 1960. He led the fight for the recognition of optometric education and the establishment of optometry as a licensed profession. Almost singlehandedly, he raised optometry to new professional levels through the high educational standards he established at the college. "Fitch understood that the transformation of the profession of optometry from opticianry would have to be built on an understanding of the needs of the public for quality vision care and the absolute importance of a proper educational foundation," said Anthony F. Di Stefano, O.D., (class of 1973), M.P.H., M.Ed., vice president emeritus and professor emeritus of Salus University. His belief that "a proper college of optometry must compete with any of the colleges of the other health professions, such as medicine and dentistry, and be on par with the best of them,"2 was the hallmark of his outstanding leadership of the profession of optometry and of PCO.

\section{BEGINNINGS}

Despite his success, optometry was not Dr. Fitch's initial career path. His first job in 1892 was at the old Philadelphia Times newspaper, where he worked as a newsboy selling papers early in the morning before the start of school. He went on to work for Vincent McLaughlin, the manager of the Philadelphia Times, for nine years and eventually became a reporter. When the ownership of the company changed, Fitch was promoted to circulation manager. When the New York Times took over the paper, Fitch was demoted and a Times staffer took over the role. Fitch resigned but was unable to secure a job at another newspaper. ${ }^{3}$

Fitch was offered a job at an advertising company where he happened to meet the optician William Fairman, co-owner of an optical business employing other doctors who wished to advance his practice. While his offer at the advertising firm was decent, he decided to take a risk and jump careers. Fitch declined the advertising position and started in the optical business for just $\$ 9$ per week. This was Dr. Fitch's introduction to the world of optometry. ${ }^{3}$ At a time when optometry was not well-regulated, Dr. Edward Gifford, a renowned ophthalmologist, saw Dr. Fitch's potential and decided to train him. Under Dr. Gifford's supervision, Fitch was allowed to see patients. He took it upon himself to practice on friends and family and learned the pathology of diseases.

\section{BECOMING A DOCTOR}

In 1906, after four years of working with Dr. Gifford, Fitch opened a successful practice in Philadelphia's Kensington neighborhood, opening two additional practices by 1912. In his autobiography Dr. Fitch explained his decision to adopt the title "doctor," reasoning that many medical "doctors" at the time took the title not because they had attended medical school, but rather because they had studied medicine under the supervision of a formally educated medical doctor. ${ }^{4}$ As he opened his practices and gained additional experience and knowledge, Fitch became more interested in organized optometry and started to attend Philadelphia Optical Association meetings. He observed, "I soon found out that any suggestions from me were unacceptable as
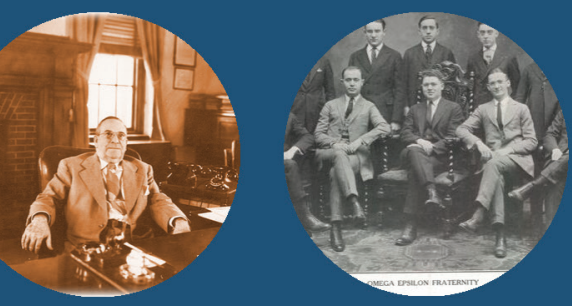
1919

CO founded as non-profit, independent college

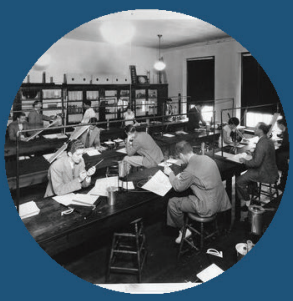

1935 1923 optometry degree conferred Four-year optometry curriculum

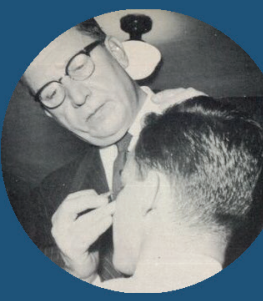
1949 (3)

First CE courses on contact lenses offered

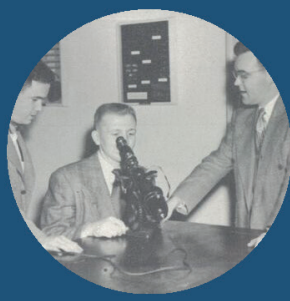

1954 implemented
Regional accreditation achieved

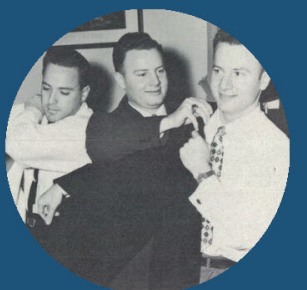

1955

Six-year optometry curriculum implemented 
being radical or as being mere flights of fancy." From time to time, his suggestions were adopted, but only after they had been introduced again by somebody else. ${ }^{4}$ He stopped attending meetings until a friend told him that, at the next one, members were voting on whether or not to join with the medical board - a vote that would give the medical board jurisdiction in the issuance of optometric licenses. That piqued Dr. Fitch's interest.

The majority of attendees at the meeting asserted that it was right to give the medical board jurisdiction. In 1913, the medical board proposed an amendment to the Medical Act of 1911 that would declare optometry a "minor branch in medicine."4 Fitch opposed the decision. He believed optometry needed to be recognized as a profession and deemed the amendment as unconstitutional. He continued to push for optometrists to practice independently from medicine, and worked to see that optometry developed and grew without being managed by another profession. Dr. Fitch became extremely passionate about optometry legislationsomething that he would fight for the rest of his life.

\section{BIGGER DREAMS}

Dr. Fitch didn't stop with legislative work. He was dedicated to improving optometric education. ${ }^{5}$ He was a founding member of the Association of Schools and Colleges of Optometry (ASCO), and in 1941, became its first president. ASCO continues today in being committed to "promoting, advancing, and achieving excellence in optometric education."6 Two decades before that, at a bill signing, Dr. Fitch overheard the Pennsylvania governor lament that optometrists in Pennsylvania would never raise their educational standards, nor create adequate educational institutions. It was then that Dr. Fitch forged full-steam ahead in the establishment of the Pennsylvania State College of Optometry (PSCO).

True to his persistent nature, Dr. Fitch took his ASCO committee to view properties in which to house the college even though the committee insisted he didn't have enough money to purchase a property. He spotted a parcel of real estate situated at 1809 and 1811 Spring Garden Street and bee-lined for them. While he did not have enough money to offer the asking price yet, he used his charm to persuade the real estate agent to work with him, as long as he was able to successfully fundraise. In the end, Fitch was able to purchase the building for $\$ 17,500$ - a $\$ 4,000$ reduction on the original price.

The Pennsylvania State College of Optometry first opened its doors on Oct. 6, 1919. Its freshman class was the largest of any school or college of optometry at that time. Thirtythree students enrolled in the three-year night school course with a tuition of $\$ 150$ for the year, and a faculty of six. In the same year, 11 of the 33 students failed the examinations and were required to drop out, which set the institution apart as a nonprofit educational institution maintaining high standards. ${ }^{?}$

What should have been an exciting time for the college was actually a time of upheaval. Dr. Fitch found himself not only as president, but also in the position of dean-a combination of which he was not fond. Pushing through these early troubles, the college held its first commencement exercises in 1922, and every member of the first graduating class successfully passed the examination given by the Pennsylvania Board of Examiners in Optometry.

From the beginning, PSCO conducted a clinic for the poor, providing eye care at no cost to them and dispensing
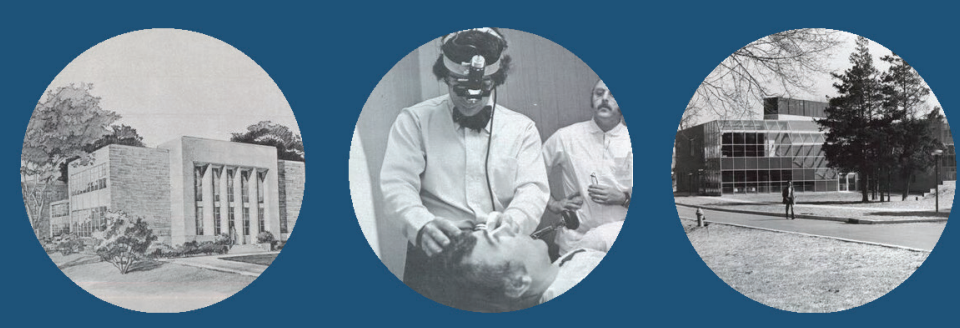

1978

1961

College receives financial

assistance from the state of

Pennsylvania
1975

Externship program launched

.

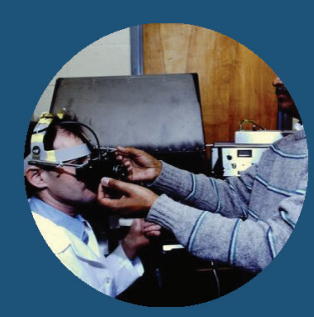

Graduate

program in vision

rehabilitation established

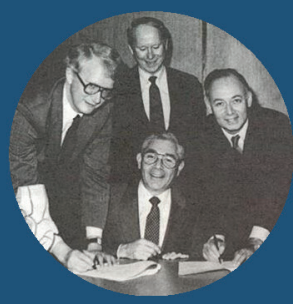

1988

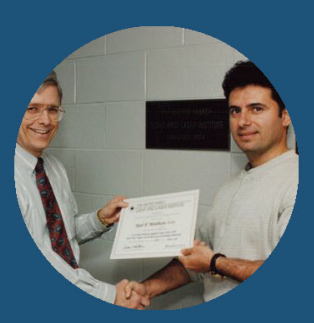

1990

Affiliation with Hahnemann

University School of Medicine
Research and training with excimer laser begins 
prescription glasses. By 1925, one of Dr. Fitch's proudest accomplishments was the acquisition of a clinical building in close proximity to the main campus. This gave the college the opportunity to establish the first fully-equipped optometric clinic in the country, complete with an ophthalmological department. 8

Patients were examined every afternoon in 11 refracting rooms and one ophthalmological treatment room. Clinical faculty included a director, two chiefs and eight unpaid assistant chiefs. Students in their final year completed all of the refracting and fitting under the direction of the faculty. Patient referrals came from social welfare agencies. Optical manufacturers and laboratories donated both lenses and frames and, when a prescription was ordered, the glasses were fabricated on-site by students and dispensed to the patient at no charge.

The college moved to a large, 32-acre campus in the Oak Lane section of Philadelphia in 1932. The Spring Garden Street building was then used solely as a clinical facility. The college became a center for the advancement of optometry research, clinical care, and the exchange of ideas among professionals. Other optometry schools began to match PSCO's entrance and graduation requirements, but PSCO was steps ahead. By 1935, the institution had increased the program length to four years - something that they were alone in doing for many years. ${ }^{9}$

\section{PERSPECTIVE}

Dr. Fitch's progressive ideals led to the introduction of Pennsylvania State House Bill No. 1119 in 1937, which would have granted optometrists full privileges to diagnose and treat eye diseases. While it fell one vote short, it was the catalyst for the transformation of optometry to a full-scope primary eye care profession..$^{10}$ Fitch's drive, boldness and spirit became the defining character of the institution. His root belief in the necessity to grow, to go beyond the norms of the day, to look beyond oneself and aspire to be more and do more, ultimately led to the decades of leadership the college demonstrated through curricular innovation, political action and clinical expansion.

After 45 years, the institution acquired a shorter and easierto-use name: Pennsylvania College of Optometry (PCO). The reason for the change was explained in an editorial in the Alumni Bulletin, "in selecting the name, the Pennsylvania State College of Optometry, our founding fathers merely fell into the pattern of the day when new banks and other new corporations were prone to use 'state' in their names."11 Through the years, the name had been the source of some trouble and confusion. Often prospective benefactors were inclined to shy away from what might be a state-owned institution and still others confused PSCO with Pennsylvania State University, which was named Pennsylvania State College until 1953.

PCO's spirit of leadership led to a number of significant innovations, such as the development of The Eye Institute, a comprehensive, interdisciplinary clinical facility for education and patient care, a comprehensive, off-campus externship program, graduate programs in the fields of blindness and visual impairment, the first international Master of Science in Clinical Optometry degree, ${ }^{12,13}$ and the expansion of offerings beyond the core program to include audiology and physician assistant studies. Today, the institution has four doctoral-level programs and 11 master's-level graduate and professional degree programs, including occupational therapy, public health, biomedicine, and speech-language pathology. In addition, the institution has wide-ranging research
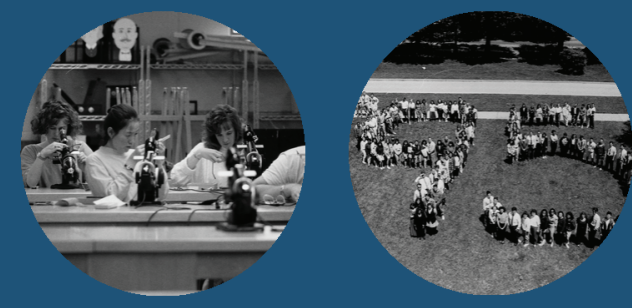

1995

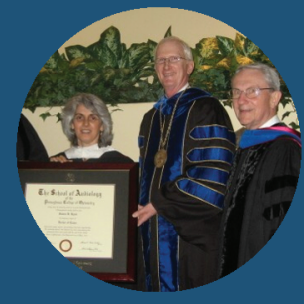

2000

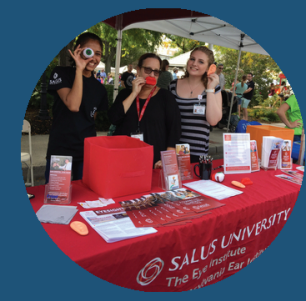

2008

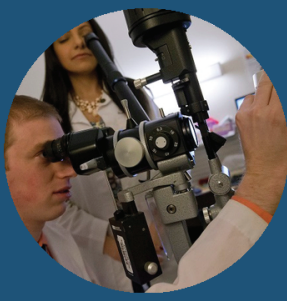

2014

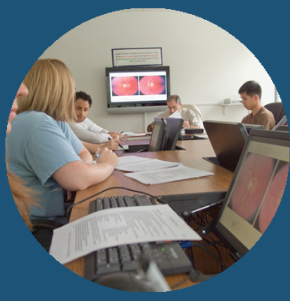

2015
National Eye Institute clinical trial begins at PCO
Master of Science in Clinical Optometry program graduates class composed solely of international practitioners
Doctor of Audiology degree program established
PCO becomes Salus University
Accelerated O.D. program launched
Two-year neuroophthalmic disease residency program launched 
initiatives and expanding clinical services, which include the Pennsylvania Ear Institute and Speech-Language Institute.

By the early twenty-first century, PCO's continued growth and diversification of educational programs led the board of trustees to approve PCO's application for university status. On January 31, 2008, PCO received official notice it had been granted university status by the Pennsylvania Department of Education. On July 1, 2008, the institution officially changed its name and status to Salus University. That nearly 90-year journey was defined by an enduring commitment to growth and a refusal to accept the status quo. The university's future would be rooted in the spirit that gave birth to its founding and gives Salus continued purpose. On July 1 , 2018, Salus University celebrated its 10th anniversary. For the duration of the 2019 calendar year, the University has also been celebrating the centennial anniversary of its founding college, which was officially commemorated with a gala in April and Centennial Tour stops through the end of the year.

\section{PURPOSE}

Notwithstanding the unique accomplishments of its first 90 years, the institution became increasingly and acutely aware of the significant internal and external challenges it must address as a private, independent institution in the twenty-first century. The diversification of its programs continually challenged its identity and demanded greater clarity in its mission and vision. A comparison of Salus' mission statements over the past 25 years reflects its story of growth and expansion, evolving from "graduating doctors of optometry..."14 to "educating healthcare professionals and educators..."15 In 2010, the university changed its disciplinecentered mission statement to one focused on patient care-a profound shift that emphasizes the university's end goal, over its means of reaching it.

Today, the mission to "advanc[e] integrated healthcare through innovative education, research and clinical services ${ }^{\prime 16}$ reinforces and expands on the university's initial foundation. The new, holistic mission provides a broad platform for growth, affirming the essence of its name, salus, the Latin term for health and well-being, embracing the interdependent goals of education, research and patient care. More importantly, it communicates the university's broad reach and impact on the global community. In a very real way, our name is our mission.

\section{WHAT'S IN A NAME?}

The institution's name change to Salus (a story in itself) brings with it fascinating history, etymology and mythology —all providing deeper and richer insight into what the university is and what it can become. The Roman goddess Salus was an enduring symbol of health, well-being, public welfare and security throughout the Roman Empire-Salus Publica Populi Romani-often depicted as a talisman on the reverse of Roman coins. Salus was considered a protector not only of individual citizens, but also the entire republic.

The root of the name Salus is even more fascinating and relevant to our mission. The word, salis, means "salt," a mineral with enduring value across time and cultures. We crave salt because of its essential importance to the health of our bodies. For centuries, nations fought over access to salt mines because of the mineral's commercial, religious, and life-sustaining value. The Himalayan salt crystal is believed to have healing power. Salt has medical utility for cleansing and has been used symbollically for purification, and protection. Our language is filled with idioms referencing the value of salt: "salt of the earth," "above the salt," "salt away," and "worth one's salt."

So, what's in a name? The name Salus provides a sharp focus for our overarching purpose. It is defining and aspirational. It bridges our past odyssey with our future direction.

\section{PROGRESS AND POTENTIAL: BUILDING ON THE FIRST 10 YEARS}

Our first decade as a university has been marked by growth. Since its inception in 2008, Salus University has added programs in public health (2010), biomedicine (2011), occupational therapy (2012) and speech-language pathology (2015), and a post-baccalaureate in health sciences (2019), adding strength to our existing programs in optometry (1919), blindness and low-vision studies (1983), audiology (2000) and physician assistant studies (2007). With this programmatic expansion, our enrollment has increased from 1,045 in fall 2010 to 1,271 in fall 2019.17,18

We have also experienced significant improvements and expansions of our facilities, including:

\section{The Eye institute}

More than $\$ 11$ million investment for the renovation of The Eye Institute (TEI), the main clinical training facility for optometry students completed in 2012. The renovation included an expansion of 14,000 square feet to the building's lower level and the integration of new and state-of-the-art ophthalmic equipment and electronic medical records. The final phase of the renovation of TEl became a reality in 2017 when a primary care facility established a primary care 
medical practice on the upper level to better serve the Oak Lane community's needs.

In 2017, the library was transformed into a Learning Resource Center that currently serves as the main focal point of our Elkins Park campus.

\section{Clinical Skills Laboratory}

Another transformative renovation that occurred in 2017 was the redesign and expansion of the Clinical Skills Laboratory for the optometry program. Long overdue, this renovation not only provided additional study and practice space for students but the adjacent Virtual Reality Lab will also significantly enrich an optometry student's ability to master important clinical skills prior to graduation and practice.

\section{Laboratories and Classrooms}

In 2018, the university doubled the size of the College of Education and Rehabilitation multipurpose lab and unveiled the campus'largest classroom in honor of Dr. Lorraine Lombardi for her dedicated service to both PCO and Salus.

\section{CONCLUSION}

The university's last decade has also been characterized by integration at the curricular, service delivery, and strategic levels. Interprofessional education (IPE) has been a natural outgrowth of curricular and service delivery integration at Salus. IPE represents a commitment to our students' future, as they are functioning within an integrated health care system that embraces medical home models and team-based group practice in addition to coordinated care.

The next 10 years of the university's evolution will undoubtedly bring forth both challenges and opportunities. The university's historical commitment is to go above and beyond the norms of the day, to look beyond itself and to aspire to be more and to do more. Salus will continue to play a leadership role in curricular innovation, political action, and clinical expansion in the decades ahead. The univerity will embrace these commitments as it considers new programs and strategic relationships which move us toward the realization of our mission of "advancing integrated healthcare through innovative education, research, and clinical services." Tomorrow's health care system will undergo profound changes in biomedicine, information technology, and artificial intelligence. The system will be impacted by shifting costs, organizational restructuring, and changing public needs and expectations. These transformations will demand that Salus seize the opportunity and responsibility for continued leadership.

So, what's in a name? Salus gives us perspective, purpose and potential. It tells a story of our past, present and future. It symbolizes health and well-being at the individual, community and organizational levels. Ultimately, it will challenge the institution to realize our life-affirming mission, coming full circle to embrace Albert Fitch's original vision. To quote T. S. Eliot: "We shall not cease from exploration, and the end of all our exploring will be to arrive where we started and know the place for the first time."

This article was compiled and adapted from previous articles by the authors appearing on the Salus University website www. salus.edu

\section{References}

1. Fitch A. My Fifty Years in Optometry. Pennsylvania: Volume I. Elkins Park: The Press of the Pennsylvania State College of Optometry, 1955; 81-83.

2. Fitch, A. My Fifty Years in Optometry. Pennsylvania: Volume II. Elkins Park: The Press of the Pennsylvania State College of Optometry, 1959; 288.

3. Fitch A. My Fifty Years in Optometry. Pennsylvania: Volume I. Elkins Park: The Press of the Pennsylvania State College of Optometry, 1955; 1-2.

4. Fitch A. My Fifty Years in Optometry. Pennsylvania: Volume I. Elkins Park: The Press of the Pennsylvania State College of Optometry, 1955; 5-7.

5. Kekevian B. Legalizing Optometry [Internet]. Reviewofoptometry.com. Review of Optometry; 2016 [cited 2019 Oct 4]. Available from: https://www.reviewofoptometry. com/article/legalizing-optometry.

6. About ASCO. ASCO: Association of Schools and Colleges of Optometry [Internet]. Optometriceducation.org. 2018 [cited 2019 Oct 4]. Available from: https://optometriceducation.org/ about-asco/

7. Fitch A. My Fifty Years in Optometry. Pennsylvania: Volume I. Elkins Park: The Press of the Pennsylvania State College of Optometry, 1955; 109.

8. Fitch, A. My Fifty Years in Optometry. Pennsylvania: Volume I. Elkins Park: The Press of the Pennsylvania State College of Optometry, 1955; 188.

9. Fitch, A. My Fifty Years in Optometry. Pennsylvania: Volume II. Elkins Park: The Press of the Pennsylvania State College of Optometry, 1959; 322.

10. American Optometric Association. The State of the Optometric Profession: 2013[Internet]. Aoa.org June 2013 [cited 2019 Oct 1]. Available from https://www.aoa.org/Documents/news/ state_of_optometry.pdf

Volume 50, Number 4, October 2019 
11. Pennsylvania College of Optometry. Alumni Bulletin 1965;18(3): 121.

12. Lewis T. Guest Editorial. J Am Opt Assoc 1996;67(4)

13. Abate, Alexis (Director of Communications, Salus University, Elkins Park, PA). Conversation with Thomas L. Lewis (Pennsylvania College of Optometry, Elkins Park, PA). 2019 September 24.

14. Pennsylvania College of Optometry. 1990-1992 Catalog. Elkin Park: Office of Admissions Pemsylvania College of Optometry, 1990.

15. Salus University. 2009-1010 Catalog. Elkin Park: Office of Admissions Salus University, 2009.

16. Salus University. Mission, Vision and Credo. www.salus.edu 2019 [cited 2019 Oct 1]. Available from: https://www.salus.edu/ About/Strategic-Planning/Mission,-Vision,-and-Credo.aspx

17. Salus University. 2018-2019 Catalog. Elkin Park: Office of dmissions Salus University, 2018.

18. Cunningham DN. What is 'Integrated Eye Care?' [Internet]. Reviewofoptometry.com. Rev Optom; 2012 [cited 2019 Oct 4]. Available from: https://www.reviewofoptometry.com/article/ what-is-integrated-eye-care

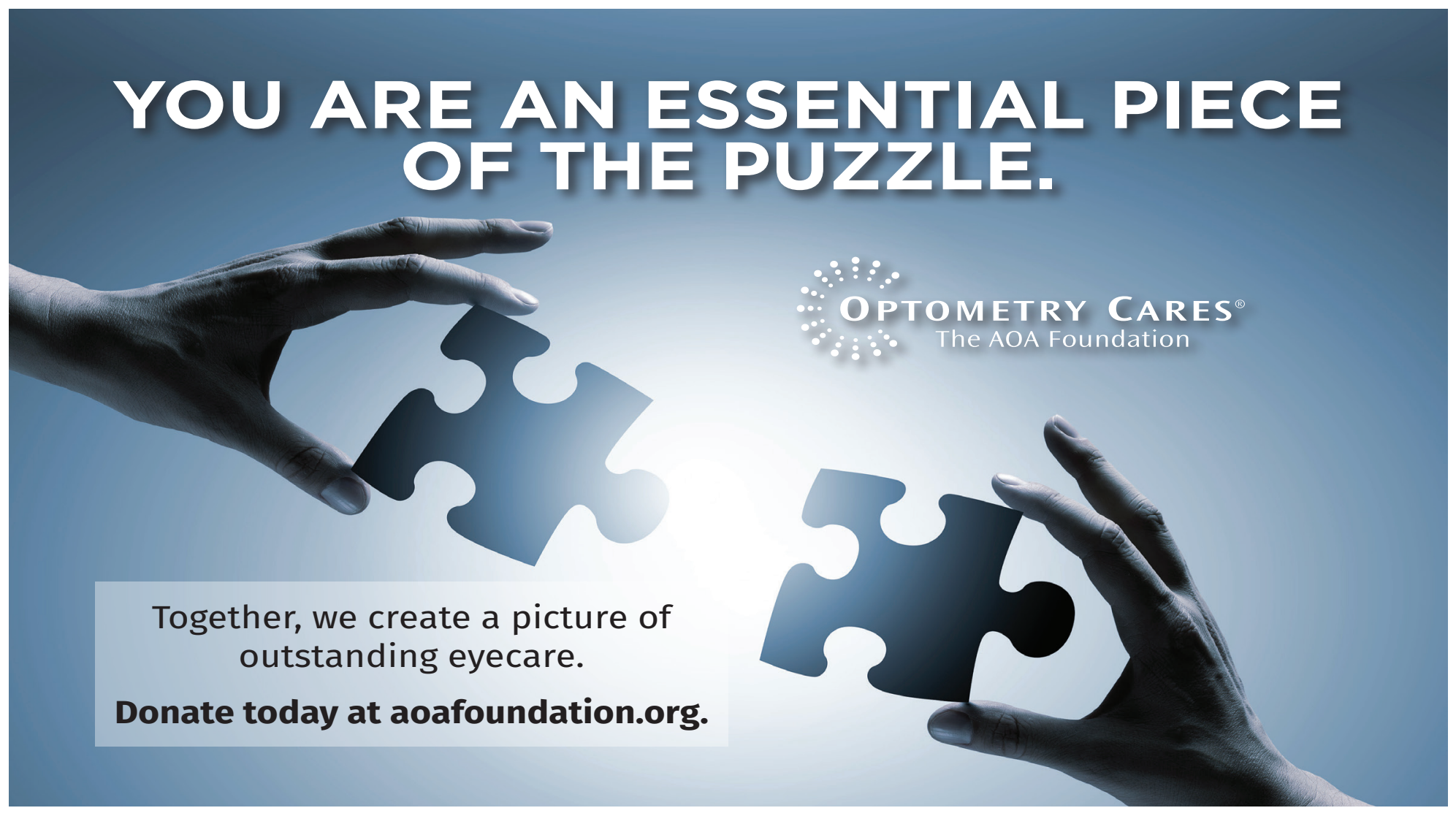

